\title{
Metamorphosis of Value in the Battle Between Preservation and Allowing Decay
}

Métamorphose des valeurs dans la bataille entre préservation et laisser-aller

\section{Kerstin Smeds}

\section{(2) OpenEdition \\ 1 Journals}

Electronic version

URL: http://journals.openedition.org/iss/520

DOI: $10.4000 /$ iss. 520

ISSN: 2306-4161

Publisher

ICOM - International Council of Museums

\section{Printed version}

Date of publication: 1 December 2015

Number of pages: $263-280$

ISSN: 2309-1290

\section{Electronic reference}

Kerstin Smeds, " Metamorphosis of Value in the Battle Between Preservation and Allowing Decay », ICOFOM Study Series [Online], 43b | 2015, Online since 06 February 2018, connection on 03 May 2019. URL : http://journals.openedition.org/iss/520 ; DOI : 10.4000/iss.520 


\title{
Metamorphosis of Value in the Battle Between Preservation and Allowing Decay
}

\author{
Kerstin Smeds \\ Department of Culture \& Media Sciences \\ Umeå University - Sweden
}

The setting is a dark future where the world has begun to fall apart. We are witnessing the end of civilization. Earth is inhabited by two sorts of creatures. One is the small good-hearted, human-like Eloi who live in small communities within large and futuristic, yet slowly deteriorating buildings, doing no work. The other is the pale and cruel Morlocks who live in dark caves and tunnels underground. Every now and then, the Morlocks will appear above ground, only to harass and chase the Eloi, then simply to eat them up. At the interface of these two worlds stands a ruined huge building called the Palace of Green Porcelain, containing heaps of oddities: a decomposing skeleton of a brontosaurus, remains of stuffed unknown animals, rusty metal objects and gadgets, a dump of ancient machines and technical apparatuses. Everywhere you see piles of trash, indefinable remnants, long since deteriorated.

Where are we? This mausoleum in decomposition is, says the author, the ancient "monument of an intellectual era", long ago vanished in the mists of Time. And the ruin itself is nothing but the remnants of the Museum of Natural History in London. The book, The Time Machine by H.G. Wells, was published in 1895. Wells is dealing with one of the crucial and most agonizing phenomena, or existential fundaments, of Western culture, which I would prefer to call a culture of disappearance $e^{110}$. This stands for our preoccupation with the dissolution of time, life and materiality, along with our desperate urge to cling to it all. With this example by Wells, I want to draw attention to the fact that what we today esteem as highly valuable and worthwhile to save, tomorrow could be considered incomprehensible and superfluous trash, and that the concept of value is continually changing over time. Today - trash, tomorrow - of museum value; or the other way round. My other point is that we, on the one hand, are preserving too much, and on the other do not take enough responsibility for what we believe we have got rid of, but which is preserved nevertheless - trash/garbage.

Museum and heritage professionals seem to believe that their job to collect and preserve objects - as well as heritagization of places and environments - somehow is an intrinsic value, which is rarely questioned or disputed. Museums and heritage institutions should start questioning their own doings. We need a deeper understanding and an overall view on the consequences of our production, collection, consuming and disposal of goods and commodities. A continued indefinite expansion of museum collections is not a realistic option for a sustainable future. A continued and indefinite expansion of production and disposal of commodities is not an option for a

\footnotetext{
${ }^{110}$ This I partly borrowed from the title of a book: Die Gesellschaft des Verschwindens by Stefan Breuer.
} 
sustainable future either; but is bringing us closer to human extinction (Kennedy, 2007).

There are two kinds of "disappearances" in our culture that I will focus on here. On the one hand, that which we do not want to be disappearing: life, time, material remains of lived life and environment, and which we therefore are trying to preserve and prevent from deteriorating. On the other hand, all that we do want to see vanished and therefore try to get rid of - material remains that we produce in our daily lives; shit, trash, poison, garbage, used, broken and worn out things. In addition, things that simply have lost their meaning or value to us - a metamorphosis that can occur all of a sudden. So there we are; we keep, to remember, and get rid of, to forget. This emotionally, morally and economically charged dichotomy is, as I see it, a driving force of our lives and culture. Further, truth about our society is located at the point where these two forces meet. This is what I will meditate on in this paper, which places itself somewhere in between heritage/museum research and the rather modern discipline of garbology (see Rathje \& Murphy, 2001; Hauser, 2001; Engler, 2004; Royte, 2005; Strasser, 1999; Rogers, 2005; Kennedy, 2007; Wagner, 2012; Humes, 2012). The archaeologists' preoccupation with garbage/refuse as a means of exploring our ancestors' way of life is not the subject of my essay.

In order to justify my subject as belonging to the field of museology, I will start with a definition - one of many - of museology the way I see it. Museology is an interdisciplinary theoretical and philosophical platform for studying the modern (industrial) man's traumatic relationship to time and to the material world, and how this is expressed in musealization and preservation of things, sites, and heritage in general. Museology examines museums, collections and heritage as phenomena of modernity. Hence, modernity always lurks in the background and actually forms the basis of this research. Museology should examine what we are really up to and why, when we continually build new museums and preserve the past. Museology conveys critical thinking in matters of musealization; investigates why and how heritage is created; and how it always changes and is reorganized along with the changing society and its values. In my view, museology examines the strategies we set up when dealing with loss as an existential, philosophical and practical problem strategies in order to stop the inexorable passage of time, to prevent entropy and deterioration and, if possible, to postpone death altogether.

My own definition comes close to the objectives of museology formulated by Peter van Mensch and Zbynek Stransky, and which François Mairesse has discussed too; "museology is the study of the specific relation between man and reality" (van Mensch, 1992; Stransky, 1995; Mairesse, 1999). The criteria of "appropriation [French: l'appropriation] of reality" would, as Mairesse notes, embrace man's interaction with the physical world.

lan Woodward has formulated a useful statement for my museological purposes:

By studying culture as something created and lived through objects, we can better understand both social structures and larger systemic dimensions such as inequality and social difference, and also human action, emotion and meaning. Objects might be seen then as a crucial link 
between the social and economic structure, and the individual actor. (Woodward, 2013, p. 4)

With the emergence of industrialization and the consumer society, four kinds of cultural institutions (if I may call them that) came into being all at once. These institutions were the (industrial) exhibition, the museum, the department store, and - the modern dump. ${ }^{111}$ All four institutions are, in addition to being products of the Enlightenment, materialism and our entanglement with objects, in one way or other connected to human social and existential concepts of Time and Being. In this paper, I will focus mainly on two of these institutions, the museum and the dump, since they form and reveal such an interesting and deep dichotomy of human action and behavior.

\section{The Museum and the Monument}

At the end of the 18th century, the march of the object into human time and space started (along with the emergence of the academic disciplines Ethnography, History, Anthropology, Archaeology). Objects and artifacts, or fragments of artifacts, were from now on used as evidence of various cultures, national identities and roots, neatly placed within systems of scientific knowledge. According to Enlightenment ideas of mastering and possessing nature, taxonomy or categorization, classification and representation were the tools with which to gain control over the world and to bridge the gap between 'thing' and 'word', between body and mind. To classify is to build systems, to structure the visible in linguistic terms, to sort the unknown into the map of knowledge. To classify is to create order out of chaos. Classification and categorization is an incessant human preoccupation that we are conducting almost every minute in our lives (Smeds, 2012). One could really say - we classify, therefore we are humans. This is a notion that could as well be attributed to Umberto Eco, who in his The Infinity of Lists examines the Western mind's predilection for making lists and the encyclopedic way of viewing the world (Eco, 2009). In a novel by the Russian avant-garde-writer Konstantin Vaginov, an "Association for collecting old and new knickknacks" is busy systematizing burnt matches, cigarette butts, candywrappers and such. One of the characters, Zjulonbin, meditates: "To classify is indeed to shape the world. Without classification there would be no memory. Without classification there would be no means to conceive of reality" (Urgesic, 2000, p. 56).

However, the field of classification was - and is - a field of conflict. Many competing theories concerning how to organize the world appeared. For a long time, there was no consensus about the classificatory structure, about what should be included and what should be excluded from these taxonomies. Classification, even for its master Carl von Linné, was a means of exclusion, not only inclusion. What was left out, which resisted integration or was impossible to fit into the system, drifted as a kind of rationality's leftovers on the backyards of civilization (Smeds 2012). The importance of museum collections for Western civilization and culture lies in the power of hiding away and forgetting, as much as in selecting and including and thus enforcing social identity work. Both of my subjects, the museum

\footnotetext{
${ }^{111}$ Definitions: a "dump" is a deposit of trash/garbage in open air, whereas a "landfill" continually, layer upon layer, is covered by mud and soil. There is also a distinction between trash and garbage; the first is "dry", more or less inorganic, whereas garbage contains all sorts of debris and is considered "wet" - includes food as well.
} 
and the dump, are situated at the core of this problem of order and disorder, inclusion and exclusion, in our inexorable entanglement with commodities. They are antipodes to one another; two sides of the same coin, as I will argue below.

Ever since the first preservation law and the Archives nationales in France were formed in $1790^{112}$, the archivization and musealization of our lived life and of things has been going on. The new régime would see to it that documents of history were rescued. French revolutionary authorities were also concerned about the unrestrained destruction of material heritage in the surge and aftermath of the Revolution. The "old regime" was crushed all right, but when demolition threatened more and more ancient buildings and monuments, authorities felt an obligation to save testimonies of the ancien régime. In 1793, the Comission des arts was founded for the purpose of protecting historical monuments. Soon thereafter, as a result of the expropriations of the Revolution, the Musée des monuments francais was created to publicly exhibit fragments from the vandalized city (Arrhenius, 2003, p. 27). Fragments - remnants - were as good as the whole object as far as testimonial properties were concerned. This was also the case in the new $19^{\text {th }}$ century museums and their collections, especially for archaeological museums of course. From the start, through preservation and conservation, modernity incorporated the past in the new as a "broken wholeness" in which the ancient monument (or object), displaced from the present, became the site of either nostalgia or utopia (Arrhenius, 2003, p. 27). The same year as the inauguration of the Commission, the Louvre instead of being demolished, as some had rightly feared, was opened to the public. From now on, heritage and museums belonged to the people.

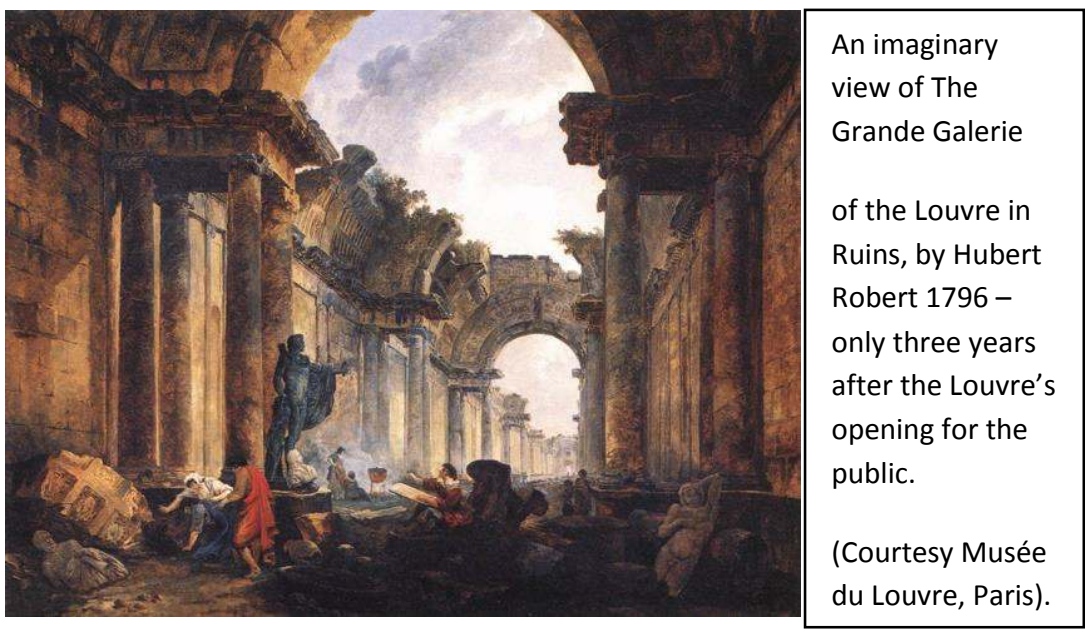

As for the protection of material heritage, in 1837 La Commission supérieure des monuments historiques was created, and the listing of protectable monuments has continued incessantly to date. Starting up with around 1000 historic monuments, the number today is tens of thousands. ${ }^{113}$ Today, the Archives nationales in France encompasses 100 shelf kilometers.

\footnotetext{
112 In many countries, such as Sweden, even earlier laws of preservation were legislated.

${ }^{113} \mathrm{http}$ ://fr.wikipedia.org/wiki/Monument_historique_(France)\#La_naissance_des_.C2.A

B_Monuments_historiques_.C2.BB. dāt. 2014-04-17.
} 
In England, laws of heritage protection were made several decades later. When The Ancient Monuments Protection Act was founded in 1882, it comprised 62 monuments worthy of preserving. One hundred years later, the number was 12800 , and this was only a fraction of all 650000 monuments and sites that actually were considered important to be protected and preserved (Hewison,1987). Today, 30 years later, the number of optionally protectable monuments in Great Britain must be at least one million. At present, British museums possess more than 350 million objects, out of which only $5 \%$ will ever be shown in any exhibition. In the United States, megalomaniac as always, the number of items in museums was over 700 million around 1990 (Weil, 2004), and by now is probably closer to one billion. In Switzerland, just to mention one example, every decade from 1970 to around 2000, 148 to 201 new museums were established. In his classic study, Heritage Industry, Robert Hewison (1987) noted that the feverish musealization was due, not only to the search for roots, but also to nations having lost the whole idea of a creative, dynamic and heterogenic society, which creates a future. Nations see themselves as already accomplished, fully developed historic identities that only remain to be preserved. This is an observation as valid today as it was in 1987. According to Friedrich Nietzsche, the obsession with history and collecting had gone too far already in the 1870s (Nietzsche,1874).

The scale of preservation has escalated relentlessly; today, everything we inhabit is potentially susceptible for preservation, including entire cities and landscapes, seas and wilderness (Bentel, 2004). Moreover, "the interval of distance in time between the present and what is preserved has accordingly shortened - if it in 1800 was 2000 years, it is by now 10-20 years or even shorter. We are living in an absurd moment when preservation seems to be overtaking us", remarks Dutch architect Rem Kolhaas (2004, p. 1). This, in turn, is due to our feverish preoccupation with history and the past - an obsession that started just around the ruptures of the French Revolution and the beginning of modernity (Steedman, 2001). "It has to do not only with opening towards the future, but with historicity and with the obligation of memory, or better, with the obligation of the archive", as Jacques Derrida puts it [his italics]. In the turmoil of revolutionary change and the emergence of modernity, Western societies were affected by a veritable "archive fever", he notes. We are "en mal d'archive: in need of archives". The "Archive" is the place where it all starts, the place that authorizes a beginning and draws up the lines of history.

\begin{abstract}
It is to burn with a passion. It is never to rest, interminably, from searching for the archive right where it slips away. It is to run after the archive, even if there's too much of it, right where something in it anarchives itself. It is to have a compulsive, repetitive, and nostalgic desire for the archive, an irresistible desire to return to the origin, a homesickness, a nostalgia for the return to the most archaic place of absolute commencement."(Derrida,1996, p. 91)
\end{abstract}

At the same time, the archive is a phenomenon that springs from our agony about our own finitude and the limits of time. The archive is made possible by death, aggression and destruction. Derrida goes on: "/.../beyond finitude as limit, there is $/ . . . /$ this properly in-finite movement of radical destruction without which no archive desire or fever could happen". Archives - and museums - came into being as establishments for salvation of cultural residue in the eternal processes of human neglect and destruction (Fayet, 2012, p. 226). In 
his investigations on time and progress, the German sociologist Hermann Lübbe has defined museums as a recompense for lack of "civilisatory" deficiency that comes with modernization. Through progressive musealization we compensate the losses we experience by rapid social changes. Progress and rapid advancement of technology has made it possible for humans to be "inhuman", not caring about consequences of our actions. The museum - and the archive - are institutions, which work as rescue stations for time and identity that would otherwise be tramped down by the high speed dynamics of global economy. Such an economy easily swallows up all local and regional identities. Thus the museum makes up for the otherwise everywhere infiltrating internationalization (Lübbe, 2004; Fayet, 2012, p. 227).

Today, after two hundred years of conservation movement and collecting, there is indeed some reason to fear that old Europe is musealizing itself, as it now has started recollecting even the present. 200 years of positivist ideas of technological progress and optimism as for the future of mankind has collapsed and turned into an allencompassing archive fever. Is not this mummification of reality a sign of a deep crisis in civilization? Museums are bulging with the mass of their enormous collections, of which only a fraction will ever be displayed in expositions. What should we do with it all? Could we treat it differently than we do now? Could we perhaps be questioning the somewhat absurd idea of "eternal preservation", which is the word of the day in the museum field? The least we could do is to take the question of disposal of museum items seriously - a discussion already under way (Davies (ed.), 2011).

The first preservation movement passed its climax in the 1920s which concurred with the peak of museums' collecting of objects in general - in Europe and the USA (Woodward, 2007, p. 7). About at the same time, the modern landfill was invented and the classical dumps were rejected or covered (Rathje \& Murphy, 1991, p. 85).

\section{Trash}

In his interesting investigation of the ontology or "being" of trash, Greg Kennedy notes that a number of themes in fact are historically combined to the phenomenon of trash in our modern society: rationalization, disembodiment, convenience, denial of mortality, dismissal of finitude, and violence (Kennedy, 2007, p. 121). Kennedy maintains that the enormous amounts of consumer trash that we produce signify in a way our failure at being human. Voluntarily, we produce commodities that do not demand our maintenance or careful attention, thus maximizing their disposability. "This relative freedom of taking care of any objects supposedly saves the consumer time. "Carefreeness" is the real promise of technology, and its real fulfilment is trash". Kennedy refers here to Heidegger and his concept of "Being-in-the-world", who distinguished between "care" [Sorge], and "taking care of" [Besorgen]. "Care" is a more profound and existential concept of being human, of "being-in-the-world". Thus the "consumption of care-free commodities in fact conspires against our own essential being as care" - meaning care as our relation to the world; care of the environmental, social and other preconditions of human existence (Kennedy, p. 122f). Kennedy is pessimistic: he finishes his book with a chapter with the headline "Human extinction". 
The modern world is indeed a world of making, producing, purchasing, encountering, ordering and valuing objects and commodities of all sorts; the global economy depends heavily on this endeavour. The consumer society is a society of endless identification, classification and creation of typologies of objects; a kind of movement or choreography we people conduct along with the biography of the objects themselves. The route is very dynamic and interactive, starting from the creation of the object, moving on to a transient world of trade. Further, it continues on to ownership (to keep things) and use; from there, either it passes to our descendants or perhaps it goes straight into the museum; or, unhappily to its antipode the trash/garbage deposit or landfill. Occasionally, objects take a detour along a third trajectory to the flea market or the secondhand store, thus sneaking back in into the world of transients and reuse through the back door.

At the end of the 1970's, Michael Thompson provoked some discussion concerning the ontology of commodities and trash with his Rubbish Theory - The Creation and Destruction of Value (1979).

Thompson attempted a comprehensive theory of value through a focus on the biographies, movements and transformations of objects as they move along from their "birth" into the world of commodities ("transients") to either the category of "rubbish" or that of "durables". Rubbish Theory looks like this:

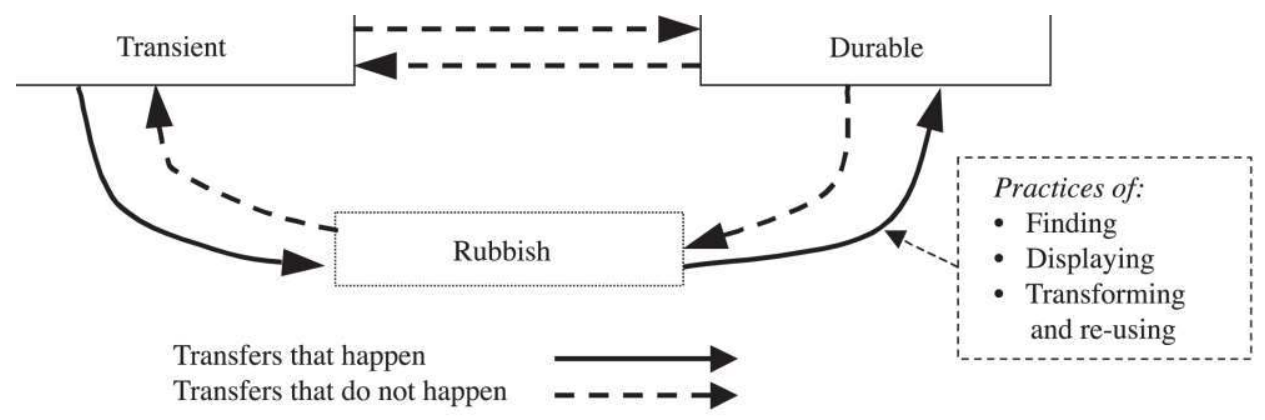

The transient represents the usual state of commodities as objects that are quickly declining in value and that have finite life spans; whereas the durables increase in value over time and have (ideally) infinite life spans (Thompson,1979, p. 7). Liz Parson notes that according to Thompson, "a transient object, gradually declining in value and in expected life-span, may slide across into rubbish where it has the chance of being re-discovered, brought to light or cherished once again" (Parson, 2008). Here, the rubbish category also comprises the flea market, where it is more likely, or at least appropriate, to find useful things than it is at the dump.

Rubbish is an integral part of social life and a key conduit through which objects move from the transient to the category of durables. The location of durables would - in my case - be the museum, or the antique shop. However, there is a serious weakness in Thompson's model; he states that the career of transients never would go straight to the category of "durable" but has to proceed via the rubbish bin, dump or flea market. In my view, objects can move very freely from transient to durable and back again, or vice versa, entirely leaving out the stop-over as "rubbish". And from the category of rubbish, an object can as easily move back to transient, if it is "discovered" and "saved" for re- or secondhand-use. Moreover, some things will be forever lost either among durables (museum) or as rubbish (dump); 
they will not make a single move any more, nor will they ever see daylight again.

Value is not something that "is" attached to any object per se. Value is never fixed. Value is in the eye of the beholder. There is a constant battle of values going on in our encounter with objects, in which the question of authenticity, time and age is involved, in which status and personal or institutional identity is involved, as well as memory, history and lots and lots of other parameters.

Meaning and value are incessantly created, processed, maintained and changed, and are linked to the "cultural capital" (Bourdieu) of the person or collective who estimates the value. Meaning and value are not qualities in the object, nor are they something independently going on in the head of those who entangle with the object, but lie in the entanglement itself. This is part of the "specific relation to reality" I am examining. Value is created by many different parameters operating both from inside (person) and outside (society), dependent on social, economic, etc. circumstances. Value and valuation is the very fundament of classification. From there categorization and classification starts. And value also governs our entanglement with objects.
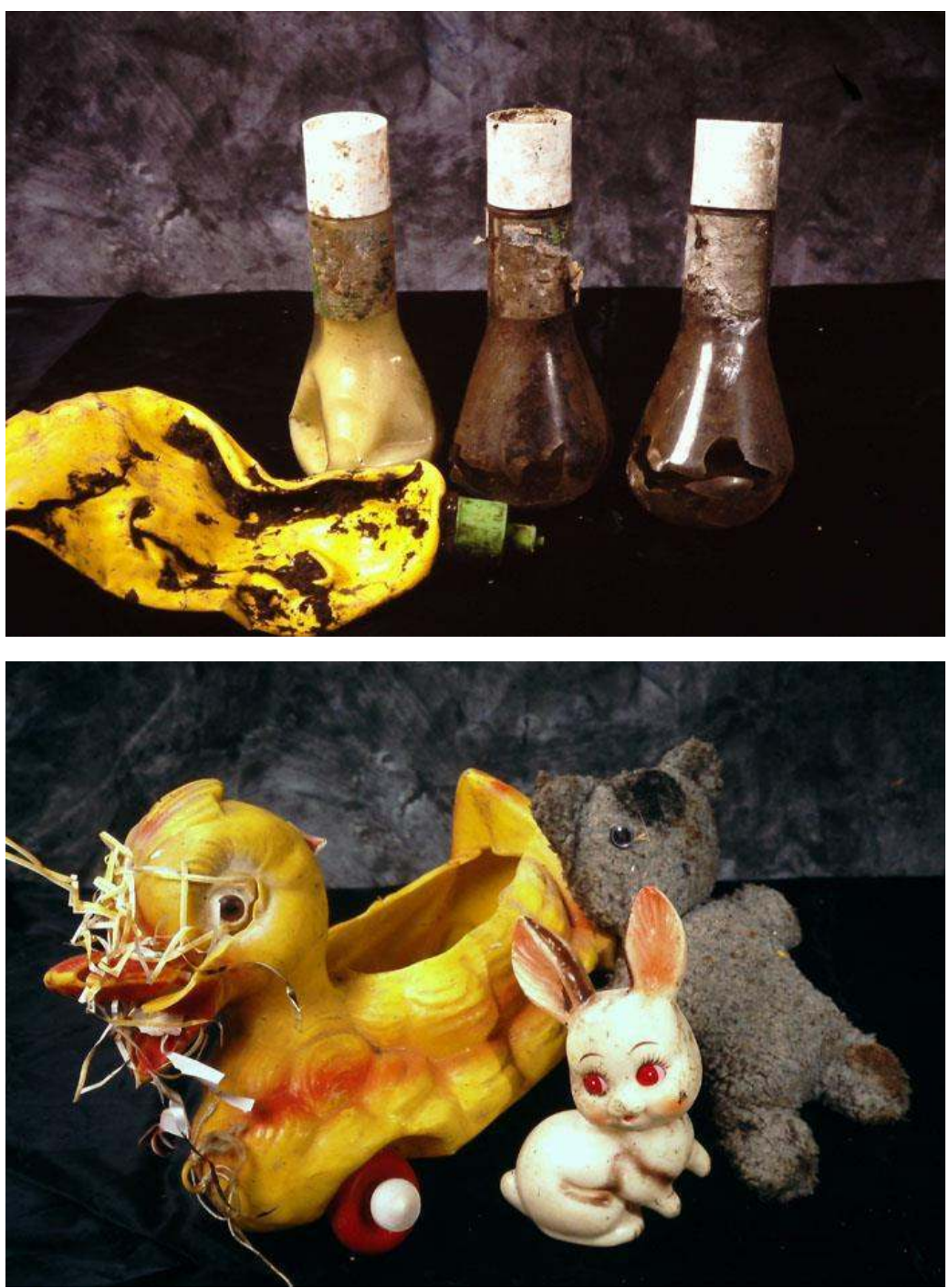


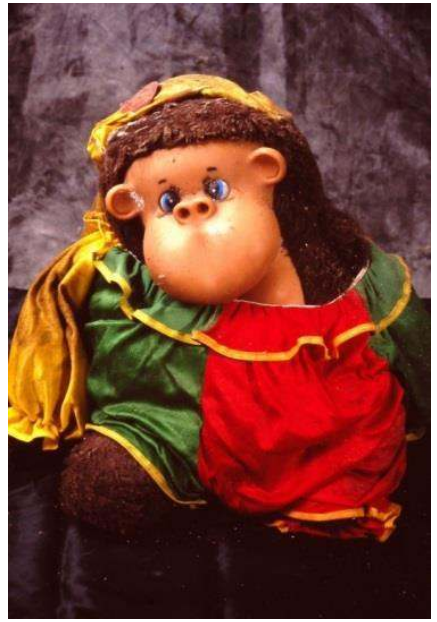

These three images are taken immediately after I, together with my friend photographer Stefan Bremer, had made a small "raid" to different dumps in the outskirts of Helsinki, and from there moved the objects to a studio to "immortalize" them or "musealize", if you like - adding new value in moving them from trash to durables.

I would like to present my personal "diagram" or "tableau" of this reality. In short, this is my "Truth-of-objects-map", which I will explain below. In the image below, I have listed a number of keywords with the aid of which I will try to make my point. I will discuss our relation to the material world. In my opinion, the "truth" about our reality and our specific relation to reality, lies somewhere between the two opposites I am mapping out in my image. ${ }^{114}$

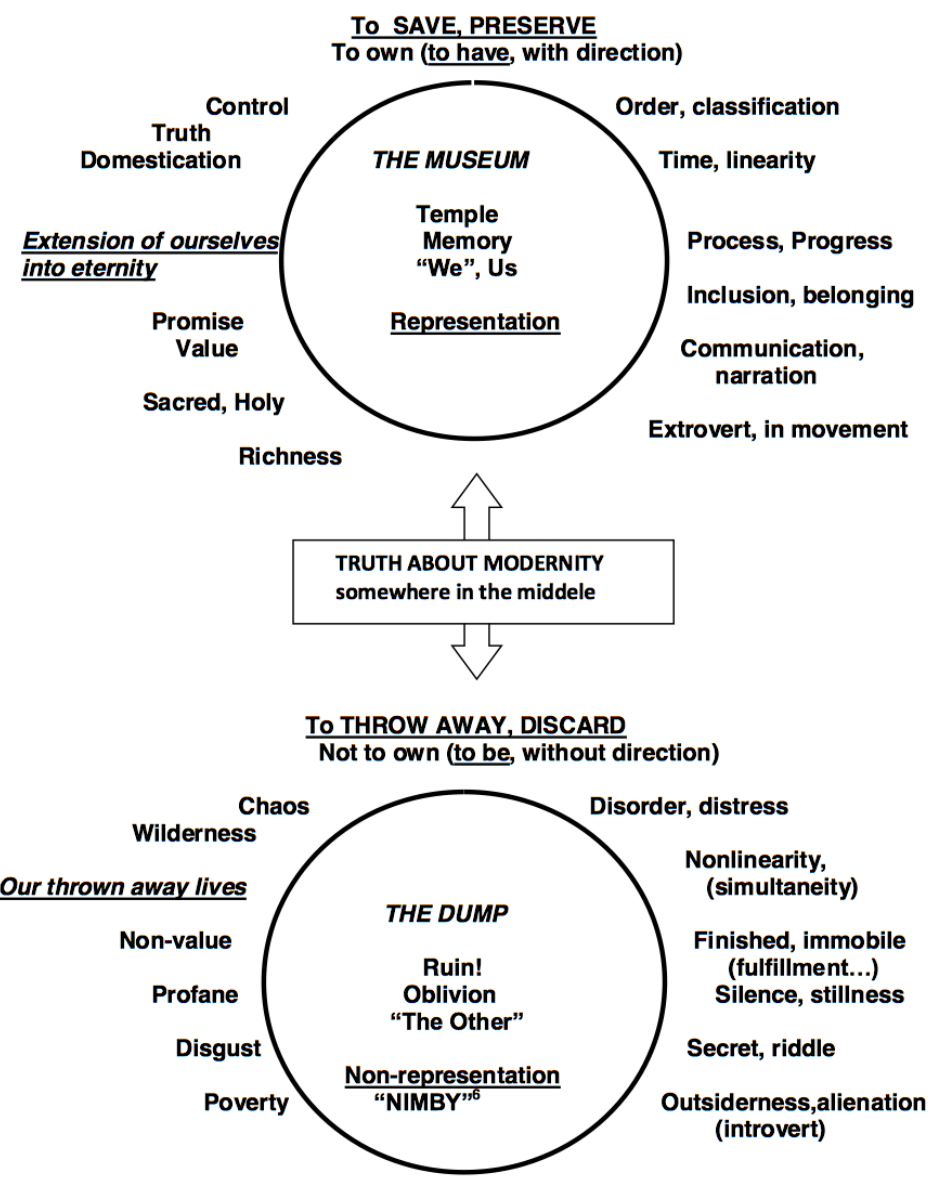

To make the picture clearer, these keywords of opposites could as well be listed in columns, one for the museum, and another for the dump. Even if they are antipodes to one another, these two

\footnotetext{
${ }^{114}$ This "map" was published as a first version in Swedish some years ago in the academic journal Nordisk Museologi [Museology in the North] but at the time it was only briefly explained (see Smeds, 2002).
} 
"institutions" have two things in common. They are both deposits for things, taken out of their practical everyday use, and they both preserve things very well, for "eternity" so to speak - however, the first by care, the other by neglect.

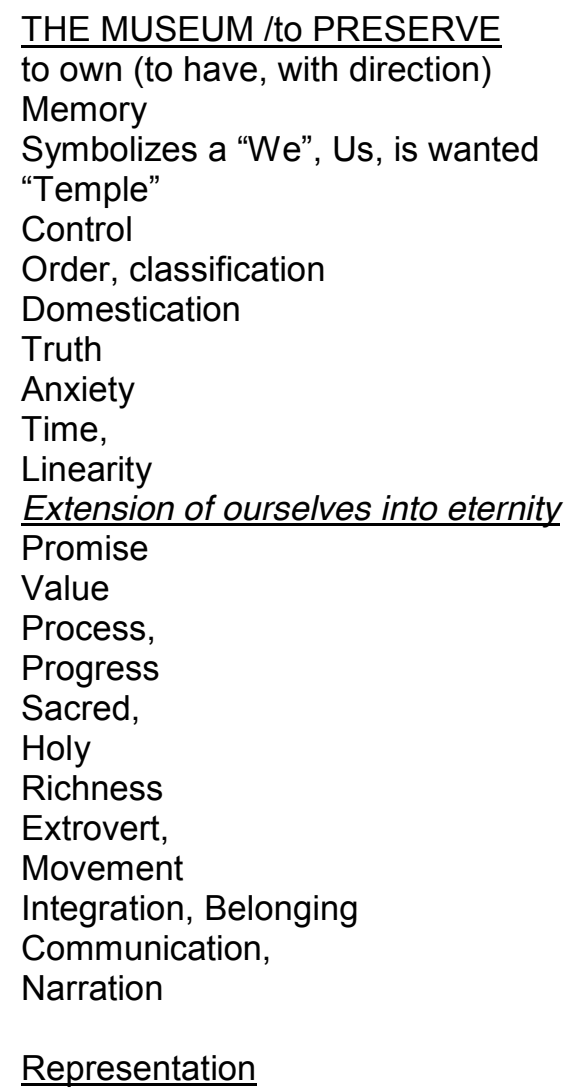

\author{
THE DUMP /to DISCARD \\ not to own (to be, without direction) \\ Forgetfulness / Oblivion \\ Symbolizes "The other", Them, not \\ wanted \\ Hell, Ruin \\ Chaos \\ Disorder, distress \\ Wilderness, "freedom" \\ Riddle / Secret \\ Relief \\ Nonlinearity, (simultaneity) \\ Our thrown away lives \\ Loss \\ Non-value \\ Finished, immobile \\ Profane \\ Poverty \\ Introvert, silence, stillness \\ Outsiderness, alienation \\ Nothingness / Neant \\ Non-representation \\ "NIMBY" (not in my backyard...)
}

First, let us note the headlines of the two antipodes of social life and meaning of objects, collected and highly valued versus non-collected, non-valued. The museum is all about having, owning, saving and preserving - in the name of science but very often for an unknown purpose. A collector would say, "I have this, therefore I am". If a museum could speak, it would say so too. This is the sphere where the rational (and technological) mind takes a grip over body and matter and uses it to its own convenience; in a world where moneyvalue and "knowledge-production" rules. The other sphere is not at all connected to ownership, but simply represents an "I am" - here at this spot in time and space, just because you have left me here, neglected, without care (Fromm, 1976).

The first sphere (museum) is heading forward; all undertakings in a museum have a purpose and direction, moving from a past towards a future. The museum posits itself in a linear chain of being in history, gathering memorabilia and material evidence of past lives, whereas the other, the dump, is posited entirely out of time. A dump/landfill or trash deposit is per definition non-linear, non-chronological, nonprogressive, non-evolutionary as far as time and history are concerned. In a dump, all possible times (items from different historical periods) could peacefully coexist within one square meter. Whereas the museum is memory, the dump is forgetfulness and oblivion. The question of memory is complex though, since the dump might also contain memories - even too many hidden memories. However, museums represent the memories we wanted to save, 
while the dump represents memories we would rather not have. The museum represents memory in neat order, whereas in the dump, memory resides in its natural state - actually in the same manner as it does in the mind of a person: ALL memories are acutely present, in no order at all until we start narrating them.

A museum and the collections in a museum, taxonomically ordered as they are, stand for control. The ontological and epistemological idea of a museum is to gain control of reality and time by structuring it scientifically. In some ways, time in a museum, particularly in the repositories of collections, is similar to that of a dump; time is "frozen", stopped. But as soon as something is done with the collections, e.g. displayed and ordered within a narrative in an exhibition, time is given a direction, it "moves" ahead, but only subordinated to our will, to decisions and trajectories. In the dump, time never moves; all layers of times are just there, in a big mess.

Due to its scientific origins and purposes, the museum of course also represents truth. The knowledge aggregated in a museum is (or was) thought to be objective truth - at least until hermeneutics intruded into and disturbed the image. A museum would say, "We are telling you the truth about reality and history. Because we know." This is the whole point of being a museum. Rarely does (or did) a museum take into account the circumstance that the narration (be it national, regional, scientific or what) in which it is subsumed, de facto only exhibited fragments and fractions of the past - and as a matter of fact the same kind of fragments that are found in a dump.

What story does a classic dump then tell? I am not saying that a dump or landfill tells the whole truth about the past; but for sure, it tells a truer story of our lives than ever a museum could do. Since the dump is in a state of creative chaos, following no linear lines of time or history, the truths and narrations do the same; multiple stories of our everyday life are buried in a dump. If a museum, with respect to the collected and preserved objects, could be conceived as an extension of our lives into eternity, the dump represents our thrownaway lives, losses and perhaps sorrows for what we have lost. But it also represents everything that we have not wanted to save for coming generations, things that were worn out and had no value, or things that we did not want anybody to see or to know that they had anything to do with us. There might be shame attached to these remains. Grief attached to a loved one's dumped things. A dump is a sort of symphony or requiem over passed modern life, a painful résumé of a civilization that got out of hand. A dump/landfill or garbage heap is crowded with secrets, dreams and hopes, or crushed dreams and hopes. In this respect, compared to the museum, the dump is telling the real truth about our lives.

On the internet, a pseudonym "Celeste" has summed up:

\begin{abstract}
Socially unacceptable, marginalized and culturally dismissed, junk is not a graveyard of our past but the gateway to our unconscious desires and imagined futures......also a symbol of our hidden lives. If Hemingway is right and human stories are like an "iceberg" with nine tenths hidden, then junk offers a bridge so we can communicate across the divide. ${ }^{115}$
\end{abstract}

Furthermore, the museum is a structure in order. A dump on the contrary stands for nothing but chaos - that is, it stands for all taxonomical leftovers. Speaking in taxonomical terms, trash consists

115 "Celeste" on: www.peteashton.com/05/08/21/wasteland.html (dat.2006-10-15). 
of all those "mutations" and "othernesses" that do not fit into the taxonomic system. In the same manner, we would say that a museum represents a domesticated reality; reality turned into social representations, symbols and meaning - in a way, disarmed reality. We know exactly what we have and for what purpose, it can never be threatening because we control it. This is not the case with dumps and landfills, which, when they occasionally pop up in our consciousness, indeed are considered threatening - morally, sanitarily and socially. A dump is where "the other" is tucked away and resides; representing all that is foreign and even disgusting to "us" - including the outcasts and lowest ranked people in a society.

A dump is all but domesticated and controlled, as far as contents are concerned. Thus, trash represents wilderness, which is located outside the territory of our ordered everyday life and our socially reliable community. Not only is it a site where we have gathered all "wild" things that we do not want to see any more in our home; dumps and landfills are usually also located in places far out in real "wilderness", preferably in some no-man's-land, wastelands with no economic potential. Hence rubbish/trash, originally made out of raw material from Mother Nature, returns to her in the dumps and landfills, buried in her embrace.

Nobody wants their waste close to their habitat - be it an individual person, family or community. The NIMBY effect, Not-in-my-backyard, pushes around waste and disposals, preferably to the other side of a fence, or a border, or to other (remote) countries. But it always ends up somewhere. Regularly, industrialized societies ship their trash and disposals - particularly problematic technology or poisonous trash to the so-called developing countries, to poor regions. One of the most crucial contradictory features of the museum versus the dump is this: the museum represents not only "us" but also "our treasures", it is all about integration, inclusion. The dump, on the other hand, is a site of alienation, reserved for "the other", the marginalized people (poor) who have been excluded from the community, who have gained no place or identification with "us". They are defined as throwaways, treated as trash, equivalent to our trashed objects and spoiled things, and are therefore "forgotten". This is what Patricia Yaeger would call "environmental racism" - a concept very well fitted to describe our treatment of trash (Yaeger, 2003, p. 109). All over the world, there are hundreds of thousands of people literally living on, and of, dumps. "Here we encounter images of environmental racism [my italics], of racial sacrifice zones and toxic dumping sites that can be located anywhere but in the white suburbs", Yaeger notes.

Out of sight, out of mind! Western rationality and technology has cleaned it all out, taking no responsibility for the consequences.

\section{Deposition as sacrifice}

Both "institutions" - the museum and the dump - collect things for either preservation or destruction and can be identified as man-made deposits of goods and commodities. We people move constantly between them - whether we are aware of it or not. The problem is that we usually recognize only one of them (the museum); the other, we would prefer to have out of sight, out of memory, out of our lives altogether. Nonetheless, our discards will not disappear easily; they keep popping up, if not in my backyard, then in yours, or someone else's. We have to face our rituals and secrets connected to objects and our consumption of them. 
Jean Baudrillard in his book The Consumer Society notes that waste need not always be considered a negative matter. Though the essence of waste contains loss and negation, there is at the same time a positive side to it. Waste has a kind of ritualistic properties perhaps similar to the museum. /.../ "all societies have always wasted, expended and consumed beyond what is strictly necessary for the simple reason that it is in the consumption of a surplus, a superfluity that the individual - and society - feel /.../ that they are alive", says Baudrillard, cited by Greg Kennedy (Kennedy, 2007, p. 10). We own things; this proves that we are alive. Waste could be seen as ritual of sacrifice, says Greg Kennedy echoing Baudrillard:

\begin{abstract}
the ritual of sacrifice performs a kind of dialectic exchange by offering back what has been received. Strictly speaking, the sacrifice is not a giving, but a returning./.../ In sacrificing, a person places something of utility outside the sphere of possible human use. Thus, the sacrificed object gains value to the extent that it escapes its use-function. With respect to utility, its value corresponds inversely to its use-function. (Kennedy, 2007, p. 14)
\end{abstract}

Here again, the parallel between museum and dump is easy to draw; to the dump we sacrifice things out of the sphere of human use on the altar of modernity, but we do this to the museum, too. From a moral point of view, it is a highly esteemed act to donate something to a museum; at the same time, you donate a bit of yourself and your name. Analogically it is our moral duty every now and then to tidy up our wardrobes and cupboards to get rid of our surplus. In both cases, the object is "taxonomically" selected, valued, taken "out of place" from its "natural" habitat and transferred to one of the "stations" of further existence: the transients, rubbish or durables. Ironically, as I have noted, both means of sacrifice are bound to be well preserved for the amazement and lionizing of future generations.

In the context of the arts, too, trash has long been seen as a rich aesthetic resource. For decades, if not centuries, artists have made the connection between trash and existential philosophy, consumerism and heritage; Marcel Duchamp, Andy Warhol, Robert Rauschenberg and Ilja Kabakov just to mention a few - and then the great "trash philosopher" Leonid Sejka (Urgesic, 2000, p. 55). Moreover, under the influence of anthropology, archaeology and environmentalism, trash has frequently been explored as material culture that articulates identity construction in the modern society (Pye, 2010). Precisely as the museums are considered to do, I would add.

\title{
The dump as monument - and museum
}

Dumps from ancient times are continually being excavated by archaeologists; the trash of past generations is brought up into daylight. Already in Roman times, in the year 50 AD in the city of Köln in Germany, it was forbidden to throw your garbage out of the window - instead, it was dumped into the harbor. Buried for ever..... Hardly could those people imagine that almost two thousand years later, more than two million objects were dug up from there, and were put into a museum. ${ }^{116}$ After maybe thousands of years in oblivion, these fragments and pieces of past lives made their journey from "rubbish"

\footnotetext{
${ }^{116}$ Writes Die Welt in May $10^{\text {th }}$ 2014. www.welt.de/print/welt_kompakt/koeln/article
} Abfall im Museum. 
to "durables" in just a few months. In a dump, particularly in a landfill, the material is much better preserved than by conservation in a museum. The deep depth of a modern landfill is absolutely void of oxygen - nothing decomposes there. So if the archaeologist digging up the ancient leftovers in Köln saw that those people had been eating luxurious fish sauce from Pompey and olive oil from Tunisia, the archaeologists/garbologists of today (and the future) digging in the vast and by now abandoned landfill of New York, Fresh Kills, will note that New Yorkers had fresh lettuce, cucumber and hamburgers for lunch in the year 1972 (Rathje \& Murphy, 2001). We can but imagine the cry of joy of future archaeologists when they sink their spades into a landfill of this day.

Speaking about monuments and preservation, the Australian archaeologist Rowland Fletcher uses the term Monstrous Visual Symbols (MVSs) for the largest monuments that any society builds for itself - from pyramids, temples and cathedrals to bridges and skyscrapers. So far, archaeologists have believed that the world's largest MVSs are the Egyptian pyramids, the Chinese wall, or the Mexican Teotihuacan with its volume of 75 million cubic feet of building material. However, Fletcher notes that today, the largest MVSs in American society are its garbage repositories! The Durham Road landfill in the San Francisco Bay area reached 150 million cubic feet in just fifteen years, and the Fresh Kills near New York City is much larger still (Rathje \& Murphy, p. 82). The garbage mountain in Fresh Kills is, needless to say, clearly visible from satellites moving in their silent orbit around the world. Time to incorporate it among the Seven Wonders of civilization!

Garbologists William Rathje and Cullen Murphy note that these Monstrous Visual Symbols may not be Chartres, but they are not without a certain grandeur. They continue, "Landfills are fitting symbols of many of the developed world's twentieth-century preoccupations - and they are great wellsprings of mythology as well" (Rathje \& Murphy, p. 82).

Trash deposits and landfills transform themselves easily into museums, heritage and monuments. Already in 1989, the Development Commission in Hackensack Meadowlands (USA) lodged a garbage museum in an environmental center. It was one striking floor-to-ceiling exhibit - a transparent tunnel forming a bright, cavernous jumble of trash - through which visitors were able to walk. (Rathje \& Murphy, p. 83). There is, or was since it is now closed (2011), a Garbage Museum in Connecticut too, the website is still on the internet (I have heard that it had reopened - but on the www there is no sign of reopening). The museum was (is?) run by the Connecticut Resources Recovery Authority in Hartford. This museum made no connections to culture or existentialism, but offered environmental and recycling educational programs including suggestions on how to implement recycling at home. Besides tours of recycling facilities led by trained educators, the museums run school and community programs. ${ }^{117}$

Many other trash museums and exhibitions have seen the light of day. In Germany there is a Museum des Abfalls, and in Vienna they are contemplating on dumps and latrines from the $12^{\text {th }}$ century, excavated and shown for the public when more tunnels for the Metro

\footnotetext{
117 http://www.crra.org/pages/Garbage_Museum.htm; coach.com/blog/2010/07/08/the-fun-green-museum-trash/ 
are dug (Fayet, 2010). And as I noted before, "garbology" is - since 25 years back - a very well established academic discipline, especially in the United States (see note $\mathrm{xx}$ ). But as far as I have noted, not many have treated the subject from the viewpoint I am here trying to put forward: trash and garbage as cultural heritage side by side with museums - be it a somewhat absurd and perverted kind of heritage - saved for our descendants as testimony of the madness of our age. What else but feelings of wonder, sorrow and nostalgia for the past would this provoke!?

Undoubtedly, there is a strain of nostalgia to trash. Junk, waste, ruins and dumps have indeed inspired modern poetry in the same manner as the ruins of antiquity inspired by $18^{\text {th }}$ and early $19^{\text {th }}$ century writers such as Shelley who, encountering ruins outside Rome, recited:

"Never was any desolation more sublime and lovely.

The perpendicular wall of ruin is cloven into steep ravines filled with flowering shrubs whose

thick twisted roots are knotted in the rifts of the stones/.../

(Woodward, 2001, p. 67)

In the same spirit but almost 200 years later, the pseudonym Celeste wrote poetically about garbage dumps on a website many years ago:

\begin{abstract}
We can wail in the wind and our voices will be held as tremulous ghosts in the discarded remains. Fragments, small parts, brief windows, junk offers tiny constellations in the human cosmos. Junk writes our lives into being by becoming more that its material parts, straining against it's definition as the detritus of existence. Junk is a spiritual elegy to survival, a testimony to a life lived and, for those whose mortgages fall apart, whose pensions never happen, whose families turn away, it is a proud way of life. Junk offers a dream world of new beginnings. Junk is a touchstone, a clairvoyant, a gatekeeper and a guardian bearing to our unconscious lives. $^{118}$
\end{abstract}

\title{
Conclusion
}

This paper is just a beginning, a short preludium; an attempt to discuss and formulate a problem and a perspective of museological research - hitherto overseen - but which really could make a difference as far as our relation to the material world, consumption/collection of objects, and the social and political role of museums of the future is concerned. It is to this end I have tried to enlarge the scope of museum activities, musealization and conservation as phenomena of modernity. My aim is to draw attention to our actions and preferences in relation to things, consumption, collecting and preservation. What are museums actually up to and why would they not at all care about the relation to the dark side of our encounter with things - the dump? Museums would have a reason to question and scrutinize their own business not only as a deposits of things highly valued, but also in relation to the reality of non-valued things "out there". Museums should beware; is their purpose to contribute to the ever-growing obsession and preservation of objects, or should they, with all their accumulated knowledge about human history, intervene in the ever increasing production and

\footnotetext{
118 September 1, 2005 on a blog: www.peteashton.com/05/08/21/wasteland.html which today is unfortunately closed. I used this quotation in one of my own articles in 2007 .
} 
consumption of commodities? Should they start to sort things out of their enormous collections?

\section{References}

Arrhenius, T. (2003). The Fragile Monument. On Conservation and Modernity. School of Architecture KTH, Stockholm.

Bentel, P. (2004). Where Do We Draw the Line? Historic Preservation's Expanding Boundaries: Future Anterior:1.

Boivin, N. (2008). Material Cultures, Material Minds. Cambridge University Press.

Derrida, J. (1996). Archive Fever. A Freudian Impression. University of Chicago Press. Chicago \& London.

Davies, P. (Ed.) (2011). Museums and the Disposals Debate. A Collection of Essays. MUSEUMSETC, Edinburgh.

Eco, U. (2009). The Infinity of Lists. An Illustrated Essay. Musée du Louvre/Rizzoli, New York.

Engler, M. (2004). Designing America's Waste Landscapes. John Hopkins University Press. Baltimore and London.

Fayet, R. (2010). Der Abfall und das Museum: Anselm Wagner ( $\mathrm{Hg}$.): Abfallmoderne. Zu den Schmutzrändern der Kultur, LIT Verlag, Stuttgart.

Fromm, E. (1976). To Have or to Be. New York, Harper \& Row.

Hauser, S. (2001). Metamorphosen des Abfalls. Konzepte für alte Industrieareale. Campus Verlag. Frankfurt / New York.

Humes, E. (2012). Garbology. Our Dirty Love Affair with Trash. Avery Publishing Group.

Hawkins, G., \& Muecke, S. (Ed.). (2003). Culture and Waste. The Creation and Destruction of Value. Rowman \& Littlefield Publishers INC. Oxford, New York.

Hewison, R. (1987). Heritage Industry. Britain in a Climate of Decline. Routledge, London.

Kennedy, G. (2007). An Ontology of Trash. The Disposable and its Problematic Nature. State University of New York Press.

Kolhaas, R. (2004). Preservation is Overtaking Us: Future Anterior.1.

Lübbe, H. (2004). Der Fortschritt von Gestern. Über Musealisierung als Modernisierung. In U. Borsdorf, et al. (Hg.). Die Aneignung der Vergangenheit. Musealisierung und Geschichte. Bielefeld 2004.

Mairesse, F. (1999). La rélation specifique. ICOFOM Study Series, ISS 31. Retrieved from: http://network.icom.museum/fileadmin/user_upload/minisites/icofom/ pdf/ISS\%2031\%20(1999).pdf\%20.pdf

van Mensch, P. (1992). Towards a Methodology of Museology. University of Zagreb, Faculty of Philosophy, Doctoral Thesis.

Nietzsche, F. (1874). Vom Nutzen und Nachteil der Historie für das Leben. Wien.

Parson, L. (2008). 'Thompsons' Rubbish Theory. Exploring the Practices of Value Creation': European Advances in Consumer Research, Volume 8.

Pye, G. (2010). Trash Culture. Objects and Obsolescence in Cultural Perspective. Cultural Interactions: Studies in the Relationship Between the Arts. Peter Lang International Academic Publishers (June 16).

Rathje, W., \& Murphy, C. (2001). Rubbish! The Arachaeology of Garbage. University of Arizona Press.

Rogers, H. (2005). Gone Tomorrow. The Hidden Life of Garbage. The New Press. New York \& London.

Royte, E. (2005). Garbage Land. On the Secret Trail of Trash. Little, Brown and Company, New York, Boston.

Smeds, K. (1996). Helsingfors-Paris. Finlands utveckling till nation på världsutställningarna 1851-1900. Svenska Litteratursällskapets Skrifter 598. Helsingfors.[Doctoral thesis on world exhibitions and national identity]. 
Smeds, K. (2002). Tankar kring det museologiska företaget. Nordisk Museologi 2.

Smeds, K. (2012). On the Meaning of Exhibitions. Exhibition Epistèmes in a Historical Perspective. Designs for Learning, Volume 5 / Number 1 $2 . \quad$ Retrieved from: http://www.designsforlearning.nu/12/no1_2/DFL_0102_12_smeds.p df

Steedman, C. (2001). Dust. Manchester University Press.

Stransky, Z. Z. (1995). Muséologie Introduction aux études. Brno, Université Masaryk.

Strasser, S. (1999). Waste and Want. A Social History of Trash. New York.

Thompson, M. (1979). Rubbish Theory. The creation and destruction of value. University of Arizona Press.

Urgesic, D. (2000). Den ovillkorliga kapitulationens museum. Panache / Albert Bonniers förlag.

Wagner, A. (Hg. 2010): Abfallmoderne. Zu den Schmutzrändern der Kultur, LIT Verlag, Stuttgart.

Weil, S. (2004). The Deaccession Cookie Jar. In S. Weil (Ed.), A Deaccession Reader. American Association of Museums. Washington. 87-92.

Wells, H.G. (1895). Time Machine. London.

Woodward, Ch. (2001). In Ruins. London.

Woodward, I. (2013). Understanding Material Culture. Sage Publications Ltd.

Yaeger, P. (2003). Trash as Archive, Trash as Enlightenment. In G. Hawkins, \& S. Muecke. Culture and Waste. The Creation and Destruction of Value. Rowman \& Littlefield Publishers Inc.

\section{Abstract}

It seems that nothing that occurs in our society today may pass untouched by the hand of preservation, which treats every happening as a past in becoming. If preservation is a product of modernity, as I will argue, so is our multifaceted relationship to objects. Museums are bulging under the pressure of their enormous collections. Experts together with politicians governed by economic rationalities, battle with the issue of what to preserve, and what to let go. At the same time, in another realm of reality, we are producing billions of tons of trash and refuse every year - material stuff, of which a large part ends up in the oceans, or in enormous landfills all over the world, tightly packed and, without question, very well preserved for coming generations of archaeologists to dig up. Museology is supposed to study man's "specific relation" to reality, particularly the material reality, and to offer guidance in how to cope with heritage in the future. This paper presents a post-humanist approach to museums and preservation at the one end and our everyday material discards and destruction of value at the other.

Key words: Material Culture, consumption, heritage, preservation, museum, dump

\section{Résumé}

Métamorphose des valeurs dans la bataille entre préservation et laisser-aller

II semble que rien de ce qui se produit dans notre société d'aujourd'hui ne peut être laissé sans passer par la préservation , envisageant chaque événement comme un passé en devenir. Si la préservation est un produit de la modernité, comme je le soutiendrai, il en va de même de notre relation multifacettes avec les objets. Les musées sont pleins à craquer sous la pression de leurs énormes collections. Experts et politiciens, régis par la rationalité économique, bataillent avec la question de ce qu'il faut conserver et ce qu'il faut laisser aller. Dans le même temps, dans un autre domaine de la réalité, nous produisons des milliards de tonnes de 
déchets dont une grande partie se retrouve dans les océans ou dans d'énormes décharges disséminées dans le monde entier, sans aucun doute très bien conservées pour les générations à venir afin que des archéologues puissent les déterrer. La muséologie est censée étudier la "relation spécifique" de l'homme à la réalité, en particulier la réalité matérielle, et offrir des conseils sur la façon de faire face au patrimoine du futur. Cet article présente une approche post-humaniste d'une part sur les musées et la préservation et d'autre part sur nos rejets quotidiens et la destruction de valeur.

Mots clé : Culture matérielle, consommation, patrimoine, conservation, musée, décharge publique 